\title{
Carboxymethyl-Starch Excipients for Gastrointestinal Stable Oral Protein Formulations Containing Protease Inhibitors
}

\author{
Patrick De Koninck ${ }^{1,3}$, Denis Archambault ${ }^{2,3,4,5}$, Francine Hamel ${ }^{1,2,3}$, Fathey Sarhan ${ }^{2}$ and Mircea Alexandru Mateescu ${ }^{1,3,4,5}$ \\ 1 Department of Chemistry \\ 2 Department of Biological Sciences \\ 3 Centre BioMed \\ ${ }^{4}$ Centre Pharmaqam, Université du Québec à Montréal, CP 8888, Succ. A, Montréal (Québec) Canada \\ ${ }^{5}$ Centre de Recherche en Infectiologie Porcine (CRIP), Université de Montréal, Saint-Hyacinthe (Québec) Canada
}

Received, November 15, 2009; Revised, March 21, 2010; Accepted, March 27, 2010; Published, April 13, 2010.

\begin{abstract}
Purpose. The aim of this study was to develop a formulation for bioactive compounds using Carboxymethyl Starch (CMS) as excipient containing protease inhibitors. This formulation provided gastroprotection of peptidic bioactive agents afforded by CMS excipient and enhanced stability against pancreatic enzymes by coformulated inhibitors of proteolysis. Such stability is needed for formulation of oral vaccines with specific antigens. Methods. CMS was synthesized by treatment of starch with monochloroacetic acid in conditions leading to a substitution degree of about $1 \mathrm{meq} / \mathrm{g}$ and used as excipient for monolithic devices (300 mg tablets). Pefabloc SC and Aprotinin inhibitors were tested in dissolution media and in formulation to prevent the degradation of released bioactive materials. To evaluate the structural integrity and biological stability of plant proteins in the CMS formulation, albumin and lipase were added to the plant protein extract as protein and enzyme markers respectively. The amount of released and recovered proteins was evaluated by SDS-PAGE and densitometric analysis. Results. Release kinetics and protein stability of our alfalfa protein extract (APE) in simulated gastric fluid (SGF) with pepsin and in simulated intestinal fluid (SIF) with pancreatin allowed us to evaluate the capacity of our formulations to protect peptide active agents against acidity and proteolysis. It was found that $1.6 \%(\mathrm{w} / \mathrm{w})$ of Pefabloc SC provides $98 \%$ protection of the released plant proteins for formulations of $30 \%$ APE with CMS. In addition, when bovine serum albumin (BSA) was added to the plant protein extract as a marker, $90 \%$ protection of the released BSA was observed. Furthermore, a much higher lipase activity was found in the releasing media when the formulations contained Pefabloc SC. Conclusion. Formulations with CM-Starch excipients and containing protease inhibitors prevents protein degradation and protect lipase activity, showing a marked potential to use for orally administered bioactive peptides and therapeutic enzymes.
\end{abstract}

\section{INTRODUCTION}

The development of mucosal vaccines for the prevention of infectious diseases has recently attracted a growing interest. This approach requires antigen with or without adjuvant that can be efficiently delivered to the mucosal immune system (1). Plants can easily be genetically transformed with genes of interest and provide an inexpensive source of proteins and other compounds that can act as bacterial and viral antigens (2). Tobacco, soy, potato and alfalfa have a strong regenerative capacity to produce large populations and high biomass within a relatively short period of time (3).
The low levels of secondary metabolites and high protein content in the leaves of alfalfa plant make it an ideal bioreactor for the production of recombinant proteins (4).

Corresponding Author : Université du Québec à Montréal, Department of Chemistry, CP 8888, Succ. A, Montréal (Québec) Canada, E-mail address: mateescu.malexandru@uqam.ca 
The main limitation for the larger use of oral vaccines resides in their high susceptibility to degradation during gastric residence due to both acidity and pepsinolytic digestion. Another major limitation is related to their sensitivity to proteolysis generated by pancreatic (trypsin, chymotrypsin) and intestinal protease at the upper intestine level.

Most infections occur or begin at the level of digestive or respiratory mucosal surfaces. For example, Shigella and Salmonella infections take place by mucosal invasion through $\mathrm{M}$ cells in the gut region (5). Therefore, administration of a vaccine at those sites is expected to induce a mucosal protective immune response. The oral vaccines are characterized by $M$ cell-mediated antigen uptake associated with the development of a sIgA (secretory immunoglobulin type A) response around the inductive sites (6). The sIgA prevent interactions between pathogens and mucosal receptors at the surface of intestinal cells. Moreover, oral vaccines can also act via the socalled mucosal immune system, which allows protection at distant mucosal sites (7). Thus, the mucosal route of vaccination has several major advantages versus the parental way.

To develop this approach, a suitable system that ensures protection of orally-administrated immunogenic proteins from the acidic gastric environment is required. In addition, the antigens must also be protected against enzymatic degradation in the small intestine, the site of the immune response (8). High Amylose Starch with more than $70 \%$ amylose and less than $30 \%$ amylopectin is largely used in pharmaceutics as filler, binder and disintegrant (9). Recently, carboxymethyl starch (CMS) was introduced as excipient for drug delivery to protect bioactive compounds against gastric acidity $(10,11)$. In acidic media, carboxylic groups become protonated and compact, limiting surrounding acidity and pepsin to penetrate inside the matrix. In neutral or weak alkaline media, protons are changed to sodium cations which hydrate, induce swelling and dissolution of the matrix that can occur at the same time as erosion $(12,13)$. Recently, a formulation consisting of carboxymethyl high amylose starch supplemented with $\mathrm{NaCl}$ was described for sustained drug release (14).
The presence of pancreatin (with alpha-amylase enzymatic activity) in simulated intestinal fluid (SIF) significantly increases the erosion rate of the modified starch (13). Pancreatic secretions also contain non-specific serine proteases (trypsin, chymotrypsin) that can damage the released proteins from orally administered dosage forms. The use of Soy Bowman Birk Inhibitors enhanced the amount of lunasin reaching the target tissue in an intact and bioactive form when orally administered (15). In our case, to prevent in vitro digestion with pancreatin, serine protease inhibitors such as Aprotinin and Pefabloc SC were added to the tablet formulation (16).

Aprotinin is a reversible pancreatic protease inhibitor of bovine origin with a broad inhibitory specificity extended to trypsin, chymotrypsin, plasmin and kallikrein $(17,18)$. In addition, due to its low toxicity and strong inhibition of luminally secreted and brush-border membrane-bound protease, Aprotinin has already been used in association with orally administered therapeutic peptides and proteins $(19,20)$, in order to prevent proteolytic digestion. Pefabloc SC or AEBSF ( 4 - [ 2 - Aminoethyl ] - benzenesulfonyl fluoride hydrochloride) is a sulfonyl fluoride irreversible protease inhibitor with negligible toxicity compared to phenyl-methylsulphonyl fluoride (PMSF) and 4Aminophenyl-methylsulphonyl fluoride (APMSF). It is also hydrolyzed slowly under weak alkaline conditions ( $\mathrm{pH}$ 8-9) (21). Pefabloc SC has already been used in the oral formulation of hexarelin, a hexapeptide with growth hormone-releasing activity, to protect it from pancreatic protease (22).

Although CMS has already been found as a gastro protective material $(11,12)$, the intestinal proteolysis still remains a problem to be solved. The novelty of our approach consists in the use of protease inhibitors co-formulated with bioactive peptides to protect against intestinal proteolysis. In this report, we describe the development of an efficient formulation using CMS including protease inhibitors as a plant-derived protein delivery system. The developed formulation provides gastric and intestinal peptide stability, two essential conditions to administer therapeutic proteins or bioactive agents such as antigen for mucosal immunity in oral vaccination. 


\section{MATERIALS AND METHODS}

\section{Materials}

High amylose corn starch (Hylon VII) was from National Starch (Bridgewater, NJ, USA). The Pepsin A from porcine gastric mucosa, the bovine serum albumin (BSA) and the microbial Lipase from Candida rugosa (EC 3.1.1.3, with 1180 units/mg solid) were obtained from SigmaAldrich Company (St-Louis, MO, USA). Pancreatin (porcine pancreas) eight times strength (with alphaamylase, lipase and proteolytic activities) was from A\&C American Chemicals Ltd. (Montreal, Qc, Canada). The acrylamide, the N,N'-methylene-bisacrylamide, and the protein molecular weight marker (Broad Range) were from Bio-Rad Laboratories (Richmond, VA, USA). The Aprotinin, the Complete ${ }^{\mathrm{TM}}$ tablets and the Pefabloc SC powder were from Roche Diagnostics (Laval, Qc, Canada).

\section{Carboxymethyl starch synthesis}

The excipient was obtained by semisynthesis (Scheme 1) as described by Schell et al. (23) and Calinescu et al. (11) with slight modifications. Briefly, $140 \mathrm{~g}$ of Hylon VII was suspended in $300 \mathrm{~mL}$ of $\mathrm{H}_{2} \mathrm{O}$ and warmed at $50^{\circ} \mathrm{C}$ under continuous stirring in a Hobart planetary mixer. A volume of $400 \mathrm{~mL}$ of $1.5 \mathrm{M} \mathrm{NaOH}$ was slowly added and the reaction medium was homogenized for $20 \mathrm{~min}$ at $50{ }^{\circ} \mathrm{C}$. Subsequently, $110 \mathrm{~mL}$ of $10 \mathrm{M}$ $\mathrm{NaOH}$ solution and $90 \mathrm{~g}$ of monochloroacetic acid (dissolved in a minimum volume of water) were immediately added to the mixture and stirred for $80 \mathrm{~min}$ at $50{ }^{\circ} \mathrm{C}$. At the end of the reaction, the mixture was neutralized with $300 \mathrm{~mL}$ of $2.33 \mathrm{M}$ acetic acid and cooled at room temperature. Salt ions were removed by washing the slurry with a solution of acetone:water $(60: 40 \mathrm{v} / \mathrm{v})$ repeating filtration and resuspension for three times. The slurry was then precipitated with pure acetone and filtered through Whatman filter paper. The recovered CMS polymeric material was dried overnight at room temperature and then sieved, to retain the powder with particles smaller than $300 \mu \mathrm{m}$.
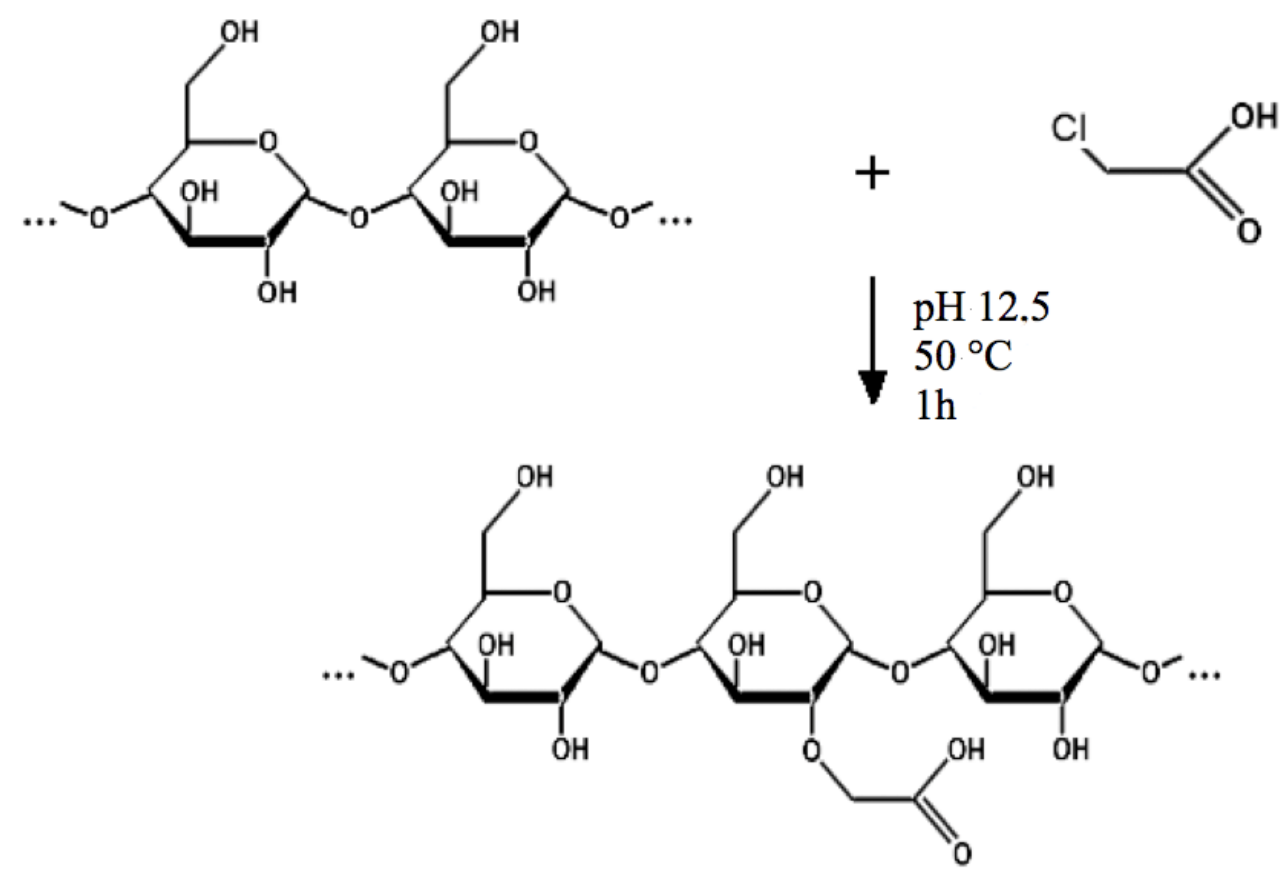

Scheme 1. Starch carboxymethylation with monochloroacetic acid 
The degree of substitution (DS) of the CMS was determined by potentiometric titration and expressed in milliequivalents of functional groups per gram of polymeric powder $(\mathrm{meq} / \mathrm{g})$. The carboxymethyl groups of the derivative were first activated by conversion into the acidic (protonated) form. Briefly, $1.5 \mathrm{~g}$ of polymer was suspended in $40 \mathrm{~mL} 0.1 \mathrm{M} \mathrm{HCl}$ solution for $20 \mathrm{~min}$ under stirring. The slurry was thoroughly washed with acetone:water $(70: 30 \mathrm{v} / \mathrm{v})$ to eliminate $\mathrm{HCl}$ excess, then with pure acetone, filtered and dried as above. An amount of $1 \mathrm{~g}$ was suspended in $50 \mathrm{~mL} \mathrm{H}_{2} \mathrm{O}$ and titrated with $0.2 \mathrm{M} \mathrm{NaOH}$ solution. The obtained value was converted into DS expressed in $\mathrm{meq} / \mathrm{g}$ giving a value of $0.92 \mathrm{meq} / \mathrm{g}$.

\section{Total protein extract}

The aerial parts of eight weeks grown alfalfa [Medicago Sativa L.] plants were collected, and ground in liquid nitrogen. The hydrated powder was kept overnight at $-80^{\circ} \mathrm{C}$ and freeze dried (Freeze Mobile 24, The Virtis Company Inc., Gardiner, NY, USA) during 5 days. Dried alfalfa protein extract (APE) was kept at $-20{ }^{\circ} \mathrm{C}$.

\section{Protein extract formulation by direct compression}

The $300 \mathrm{mg}$ CMS tablets $(9 \mathrm{~mm}$ diameter, $3.3 \mathrm{~mm}$ thickness) were produced by direct compression using Carver hydraulic press (Carver inc., Wabash, IN, USA) at $2.5 \mathrm{~T}$ of mixed dry powders of CMS and various amounts of APE containing or not BSA $1 \%(\mathrm{w} / \mathrm{w})$ or Lipase $1 \%(\mathrm{w} / \mathrm{w})$ as markers. Protease inhibitors, Aprotinin or Pefabloc SC, were integrated into the excipient at various loading for the tablets preparation (Table 1). Neither enteric coating nor other components were added to the formulation.

\section{Stability of alfalfa proteins, BSA and Lipase in simulated gastric fluid (SGF)}

Samples of alfalfa protein extract (APE), APE supplemented with BSA $1 \%(\mathrm{w} / \mathrm{w})$, or APE supplemented with Lipase $1 \%(\mathrm{w} / \mathrm{w})$ were individually incubated in $10 \mathrm{~mL}$ of acidic SGF $(\mathrm{HCl}$ $0.26 \%, \mathrm{NaCl} 0.2 \%, \mathrm{pH} 1.2)$ pepsin-free or containing $0.32 \%$ pepsin, $1.17 \mathrm{U} / \mathrm{mg}$ (USP, 1990) for 60 and $120 \mathrm{~min}$ under gentle rotation at $50 \mathrm{rpm}$ and $37^{\circ} \mathrm{C}$. At the end of the incubation period, samples of $200 \mu \mathrm{L}$ of the acidic solution were precipitated with cold acetone $(1: 5 \mathrm{v} / \mathrm{v})$ and the stability of the alfalfa proteins and BSA checked using SDS-PAGE electrophoresis and quantified by Integrated Optic Density (IOD). The activity of the free Lipase in these conditions was determined using samples of $200 \mu \mathrm{L}$ withdrawn after each hour of incubation. The enzymatic activity was stopped with liquid nitrogen.

Table 1. Formulation* of APE with CMS excipient containing or not protease inhibitors

\begin{tabular}{|c|c|c|c|}
\hline Formulation* & Bioactive Agent with BSA or Lipase as markers & CMS excipient & Protease inhibitors \\
\hline 1 & APE $24.75 \%+$ BSA $0.25 \%$ & CMA $75.0 \%$ & \\
\hline 2 & APE $19.80 \%+$ BSA $0.20 \%$ & CMA $20.0 \%$ & \\
\hline 3 & APE $29.70 \%+$ BSA $0.25 \%$ & CMA $70.0 \%$ & \\
\hline 4 & APE $39.60 \%+$ BSA $0.25 \%$ & CMA $60.0 \%$ & \\
\hline 5 & APE $49.50 \%+$ BSA $0.25 \%$ & CMA $50.0 \%$ & \\
\hline 6 & APE $29.70 \%$ + BSA $0.25 \%$ & CMA $69.5 \%$ & Aprotinin $0.5 \%$ \\
\hline 7 & APE $29.70 \%+$ BSA $0.25 \%$ & CMA $60.0 \%$ & Aprotinin $1.0 \%$ \\
\hline 8 & APE $29.70 \%+$ BSA $0.25 \%$ & CMA $69.2 \%$ & Pefabloc SC $0.8 \%$ \\
\hline 9 & APE $29.70 \%+$ BSA $0.25 \%$ & CMA $68.8 \%$ & Pefabloc SC $1.2 \%$ \\
\hline 10 & APE $29.70 \%+$ BSA $0.25 \%$ & CMA $68.4 \%$ & Pefabloc SC $1.6 \%$ \\
\hline 11 & APE $29.70 \%+$ BSA $0.25 \%$ & CMA $70.0 \%$ & \\
\hline 12 & APE $29.70 \%+$ BSA $0.25 \%$ & CMA $68.4 \%$ & Pefabloc SC 1.6\% \\
\hline
\end{tabular}


Tablets (300 mg) of CMS containing $25 \%$ of APE, APE with BSA $1 \%(\mathrm{w} / \mathrm{w})$ or APE with Lipase $1 \%(\mathrm{w} / \mathrm{w})$ were incubated under the conditions described above before being transferred into $10 \mathrm{~mL}$ of PBS solution for total dissolution under gentle agitation at $4{ }^{\circ} \mathrm{C}$. The integrity of the protein content in these formulations was evaluated for alfalfa proteins, BSA and Lipase by SDS-PAGE and measurement of enzymatic activity.

\section{Delivery of formulated alfalfa proteins, BSA and Lipase in simulated intestinal fluid (SIF)}

Tablets of APE, APE with BSA $1 \%(w / w)$ or APE with Lipase $1 \%(\mathrm{w} / \mathrm{w})$ formulated with CMS were incubated for $2 \mathrm{~h}$ in $10 \mathrm{~mL}$ of SGF containing $0.32 \%$ pepsin $(\mathrm{pH} \mathrm{1.2)}$ and then transferred for $6 \mathrm{~h}$ in $10 \mathrm{~mL}$ of SIF $\left(\mathrm{KH}_{2} \mathrm{PO}_{4} 0.68 \%\right.$, NaOH $0.0615 \%$, $\mathrm{pH} 6.8$ ), with or without $8 \mathrm{X}$ pancreatin, $0.125 \%$ (USP, 1990) at $50 \mathrm{rpm}$ and $37^{\circ} \mathrm{C}$. Released proteins were withdrawn every hour and evaluated by SDSPAGE. The enzymatic degradation of the released protein was stopped with cold acetone $(1: 5 \mathrm{v} / \mathrm{v})$.

\section{Sodium dodecyl sulphate-polyacrylamide gel electrophoresis (SDS-PAGE)}

The degradation state of alfalfa proteins and BSA was evaluated using SDS-PAGE with IOD. This procedure is adequate for the evaluation of peptide stability given information on concentrations and also on the molecular weights (indicated by its eventual degradation). Similar approach was used by Caparo et al., (24) to evaluate susceptibility of Lupin gamma-conglutin to proteolytic enzymes. Samples of $200 \mu \mathrm{L}$ of the dissolution media were collected during the incubation in SGF or dissolution in SIF and precipitated with cold acetone $(1: 5 \mathrm{v} / \mathrm{v})$, kept at $-20{ }^{\circ} \mathrm{C}$ during at least $6 \mathrm{~h}$, and then centrifuged, dried, and resuspended in $75 \mu \mathrm{L}$ of PBS. A volume of $75 \mu \mathrm{L}$ of electrophoresis loading buffer $(0.12 \mathrm{M}$ Tris- $\mathrm{HCl}$ $\mathrm{pH} 6.8, \quad 4 \%$ SDS, $20 \%$ glycerol, $10 \% \quad \beta-$ mercaptoethanol and $0.004 \%$ bromophenol blue) was added to each sample and then heated for $2 \mathrm{~min}$ at $95{ }^{\circ} \mathrm{C}$. A volume of $15 \mu \mathrm{L}$ of each samples was loaded onto a $12 \%$ polyacrylamide gel and run at room temperature for $1.5 \mathrm{~h}\left(120 \mathrm{~V}\right.$ Bio- $\mathrm{Rad}^{\mathrm{TM}}$ power supply) using an electrophoresis running buffer $(0.025 \mathrm{M}$ Tris-Base $\mathrm{pH} 8.3$ containing $0.192 \mathrm{M}$ glycine and $0.1 \%$ SDS). Molecular weight protein markers (Broad Range) were loaded as reference. Proteins were stained with R-250 Coomassie blue and gels were dried between cellulose sheets.

\section{Densitometric analysis}

Densitometry was carried out using the Quantity One 1-D Analysis program (Bio-Rad ${ }^{\mathrm{TM}}$ ). For each band, the program evaluated the surface $\left(\mathrm{mm}^{2}\right)$ and multiplied by its corresponding measured density to obtain the integrated optic density (IOD). The percentages of variation in the band densities were determined for each sample compared to those of the standard (free or formulated APE or APE with BSA (1\%) in PBS at time zero) set at $100 \%$.

\section{Determination of Lipase activity}

Lipase activity was determined as described by Cherry and Crandall procedure (USP, 1990), using an emulsion of olive oil as substrate. Briefly, $4.5 \mathrm{~mL}$ olive oil, $18 \mathrm{~mL} \mathrm{H}_{2} \mathrm{O}, 2.5 \mathrm{~mL}$ of $0.2 \mathrm{M}$ Trizma Buffer (pH 7.7), $2.5 \mathrm{~g}$ Arabic gum, $1 \mathrm{~mL}$ of a solution containing $0.015 \mathrm{M} \mathrm{CaCl}_{2}, 1.2 \mathrm{M} \mathrm{NaCl}$ and $0.011 \mathrm{M}$ Sodium taurodeoxycholate were incorporated in the emulsion by ultrasonication with a Vibra cell sonicator (Sonic Materials Inc., Danbury, CT, USA). A volume of $2.5 \mathrm{~mL}$ of emulsion was incubated for $2 \mathrm{~h}$ at $37^{\circ} \mathrm{C}$ with $200 \mu \mathrm{L}$ of enzyme sample solution. Two drops of thymolphtalein $0.9 \%(\mathrm{w} / \mathrm{v}) \mathrm{pH}$ indicator were added to the emulsion and the Lipase enzymatic activity was determined by titration of the produced oleic acid with $0.2 \mathrm{M} \mathrm{NaOH}$ until the solution turned into a light blue color.

\section{RESULTS}

Both alfalfa proteins and BSA, used as a marker, were protected against gastric acidity and pepsinolytic conditions when formulated with CMS. The SDS-PAGE showed more than $90 \%$ of protection after $1-2 \mathrm{~h}\left(37^{\circ} \mathrm{C}\right.$ and $\left.50 \mathrm{rpm}\right)$ of incubation in SGF with or without pepsin (Figure 
1a, b, lanes 7-10, and c). After incubation of tablets in SGF with pepsin, a limited proteolytic breakdown of $5 \%$ of formulated protein was observed (data not shown). Free alfalfa proteins and free BSA showed $\mathrm{pH}$ sensibility with a loss of $30 \%$ after 1 or $2 \mathrm{~h}$ of incubation in SGF without pepsin (Figure 1a, b, lanes 3 and 5, and c). In SGF with pepsin, free alfalfa proteins and BSA were almost completely degraded after the same times of incubation (Figure 1a, b, lanes 4 and 6, and c).
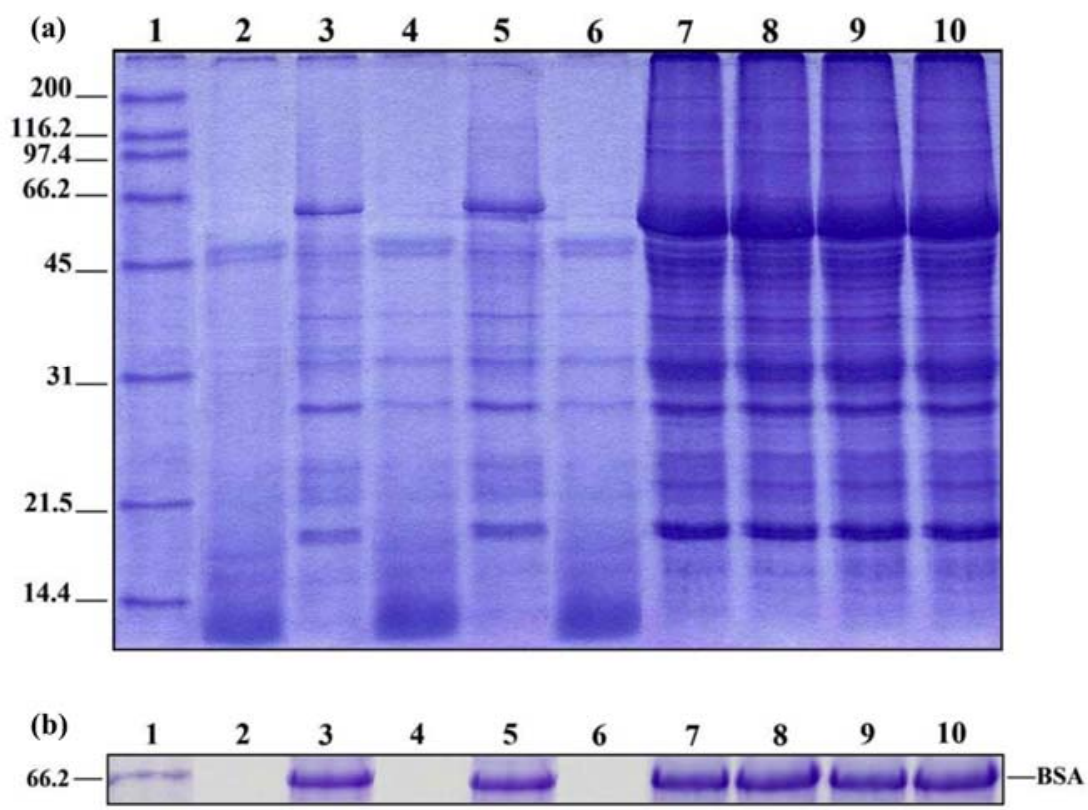

(c)

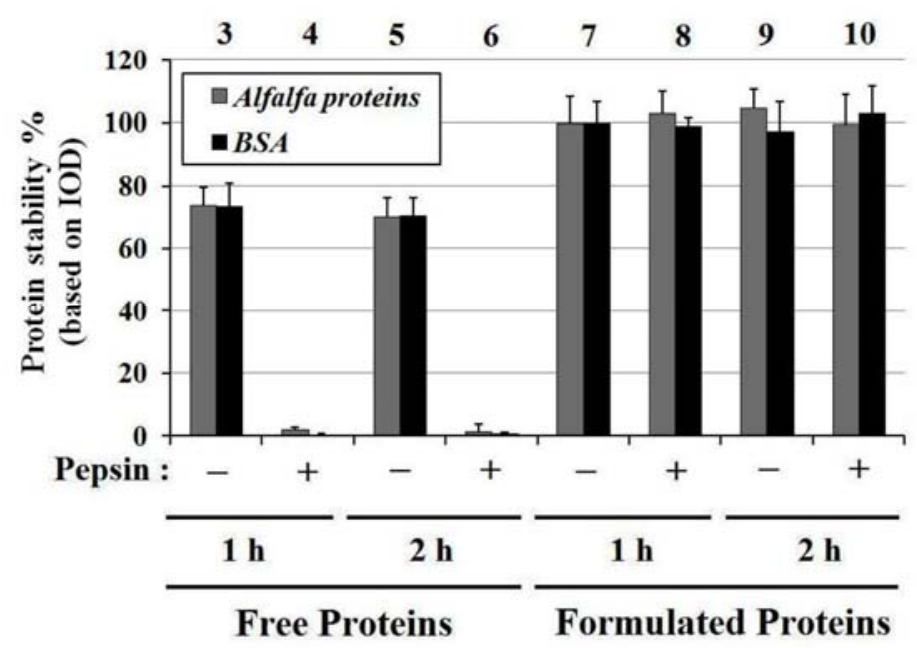

Figure 1. Stability of proteins in simulated gastric fluid (SGF/USP): (a) SDS-PAGE pattern of alfalfa proteins; (b) SDSPAGE of BSA marker (1\%) in alfalfa protein extract (APE); (c) Densitometric analysis of SDS-PAGE based on IOD. Electrophoretic profiles: molecular weight of protein markers (kDa) (lane 1); Pepsin in simulated gastric fluid (lane 2); Free (non-formulated) proteins in SGF (without pepsin) after $1 \mathrm{~h}$ (lane 3) and $2 \mathrm{~h}$ (lane 5); Free proteins in SGF with pepsin after $1 \mathrm{~h}$ (lane 4) and $2 \mathrm{~h}$ (lane 6); Proteins formulated with CMS (tablets) after incubations times of $1 \mathrm{~h} \mathrm{(lane} \mathrm{7)} \mathrm{and} 2 \mathrm{~h}$ (lane 9) in SGF without pepsin, and $1 \mathrm{~h}$ (lane 8) and $2 \mathrm{~h}$ (lane 10) in SGF with pepsin. Volume of the samples: $15 \mu \mathrm{L} / \mathrm{well}$; IOD, integrated optic density $(n=3)$. 

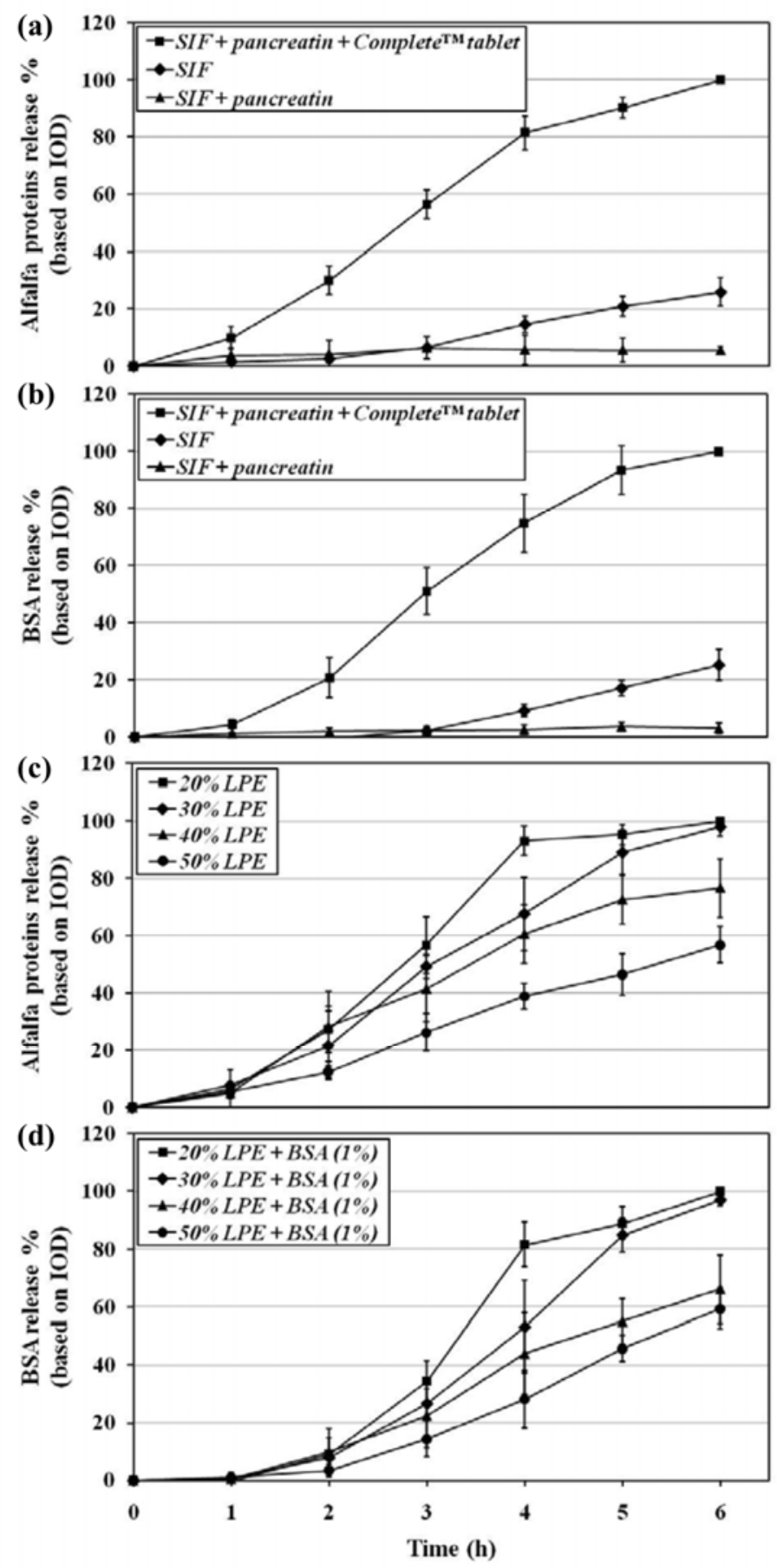

Figure 2. Release of proteins from CMS tablets in simulated intestinal fluid (SIF/USP). The tablets ( $300 \mathrm{mg})$ containing $25 \%$ of (a) alfalfa protein extract (APE) or (b) APE with BSA marker (1\%), or loading of (c) 20 to $50 \%$ APE or (d) 20 to $50 \%$ LPE with BSA $\left(1 \%\right.$ were incubated $\left(37^{\circ} \mathrm{C}\right.$ and $\left.50 \mathrm{rpm}\right)$ for $2 \mathrm{~h} \mathrm{in} 10 \mathrm{~mL}$ of simulated gastric fluid containing pepsin (SGF/USP). Then they were transferred to (a) and (b) $10 \mathrm{~mL}$ of SIF without enzymes, SIF with pancreatin and SIF with pancreatin and protease inhibitors (Complete ${ }^{\mathrm{TM}}$ tablets) or to (c) and (d) $10 \mathrm{ml}$ of SIF with pancreatin and protease inhibitors (Complete ${ }^{\mathrm{TM}}$ tablets). The samples were withdrawn every hour for $6 \mathrm{~h}$ and protein stability was determined by SDS-PAGE. Volume of the samples: $10 \mu \mathrm{L} /$ well; IOD, integrated optic density $(\mathrm{n}=3)$. 
The CMS tablets containing APE and APE with BSA $(1 \% \mathrm{w} / \mathrm{w})$ showed a slow release of proteins in SIF in absence of the pancreatic enzymes (Figure 2a, b). Pancreatin contains alpha-amylase, lipase and important proteolytic activity related mainly to serine protease such as trypsin and chymotrypsin. Due to the susceptibility of alfalfa proteins and of BSA to proteolytic degradation, very low levels of proteins were observed on SDS-PAGE gels when pancreatin was present in the SIF (Figure 2a, b). To determine the release kinetics of the formulated proteins in SIF with pancreatin, Complete ${ }^{\mathrm{TM}}$ tablets containing protease inhibitors were added to the dissolution media. These dissolved inhibitors prevent the proteolytic activity, allowing the release of plant proteins and of BSA in pancreatic conditions without noticeable degradation.

Our current formulations were loaded with $25 \%$ of APE with or without marker. As formulations loaded with more plant proteins are expected to enhance the immune response, the release curves from CMS tablets loaded with $20 \%$, $30 \%, 40 \%$ and $50 \%$ of APE or APE with BSA marker were evaluated in SIF containing pancreatin and protease inhibitors dissoluted from the Complete $^{\mathrm{TM}}$ tablets. The results in Fig $2 \mathrm{c}$ and $\mathrm{d}$ showed that formulations loaded with 20 and $30 \%$ released $100 \%$ of proteins in $4-5 \mathrm{~h}$, a period compatible with the time necessary for an orallyadministrated immunogenic agent to reach the small intestine where the immune response is initiated. The formulations loaded with 40 and $50 \%$ showed, over a $6 \mathrm{~h}$ period, a release of 75 to $55 \%$ for the plant proteins and 65 to $60 \%$ for the BSA marker, respectively. It appears that increased loading with APE generates more compact structures after compression. Thus, the loading with $30 \%$ that allowed total release of APE or of APE + BSA marker in 4-5 $\mathrm{h}$ was used for the remaining study.

The delivery of alfalfa proteins in SIF containing pancreatin and $0.015 \%$ or $0.030 \%$ $(\mathrm{w} / \mathrm{v})$ Aprotinin showed $50 \%$ protection for both concentrations of the inhibitor (Figure 3a). In contrast, only $15 \%$ of BSA was recovered for both Aprotinin concentrations in the dissolution media (Figure 3b). Under $0.025 \%$ or $0.050 \%(\mathrm{w} / \mathrm{v})$ Pefabloc SC (concentration comparable or twice higher than those released by Complete ${ }^{\mathrm{TM}}$ tablets) in the SIF, $100 \%$ protection of APE was achieved at the end of the incubation (Figure 3a). For the BSA marker, similar protection with $100 \%$ recovery was obtained for both concentrations of Pefabloc SC (Figure $3 b$ ). Indeed, for both alfalfa proteins and BSA, $0.025 \%(\mathrm{w} / \mathrm{v})$ of Pefabloc SC in SIF was sufficient to afford protection similar to that obtained with Complete $^{\mathrm{TM}}$ tablets (one per each dissolution medium) (Figure 2a and $\mathrm{b}$ ). As control, no protein recovery was observed in the absence of protease inhibitors in the SIF (Figure $2 \mathrm{a}, \mathrm{b}$ and Figure 3).

For appropriate delivery of immunogens to specific immune sites along the small intestine, a combined formulation allowing a simultaneous release of proteins and the inhibition of serine protease was tested by incorporating Aprotinin or Pefabloc SC into the polymeric excipient. The delivery of proteins from formulations loaded with $30 \%$ APE and $0.5 \%$ or $1.0 \%(\mathrm{w} / \mathrm{w})$ of Aprotinin was assessed in SIF containing pancreatin. Recoveries of $55 \%$ or $60 \%$ of released alfalfa proteins (Figure $4 \mathrm{a}$ ) and of $10 \%$ or $15 \%$ of released BSA marker (Figure $4 \mathrm{~b}$ ) were observed.

When Pefabloc SC was used in the formulation, a lesser degradation of the released alfalfa proteins was observed. Recovery rates of $70 \%, 80 \%$ or $95 \%$ of proteins in SIF were observed when the tablets contained $0.8 \%, 1.2 \%$ or $1.6 \%(\mathrm{w} / \mathrm{w})$ of Pefabloc SC (Figure 4a). Furthermore, for the tablets containing $1.6 \%(\mathrm{w} / \mathrm{w})$ of Pefabloc SC, the alfalfa proteins release profiles were similar to those obtained with the Pefabloc SC added in the dissolution medium (Figure 3a). In contrast, BSA appeared to be more susceptible to proteolysis. This degradation was prevented by the Pefabloc SC content of the formulation in a concentrationdependent manner. Thus, for tablets containing $0.8 \%$ or $1.2 \%(\mathrm{w} / \mathrm{w})$ of Pefabloc SC, a good recovery of $55 \%$ or $70 \%$ of BSA were respectively found in the release medium. When $1.6 \%(\mathrm{w} / \mathrm{w})$ of Pefabloc SC was used in the formulation, the protection was even higher, with $90 \%$ of the BSA recovered in the dissolution medium at the end of the release process (Figure $4 b$ ). 

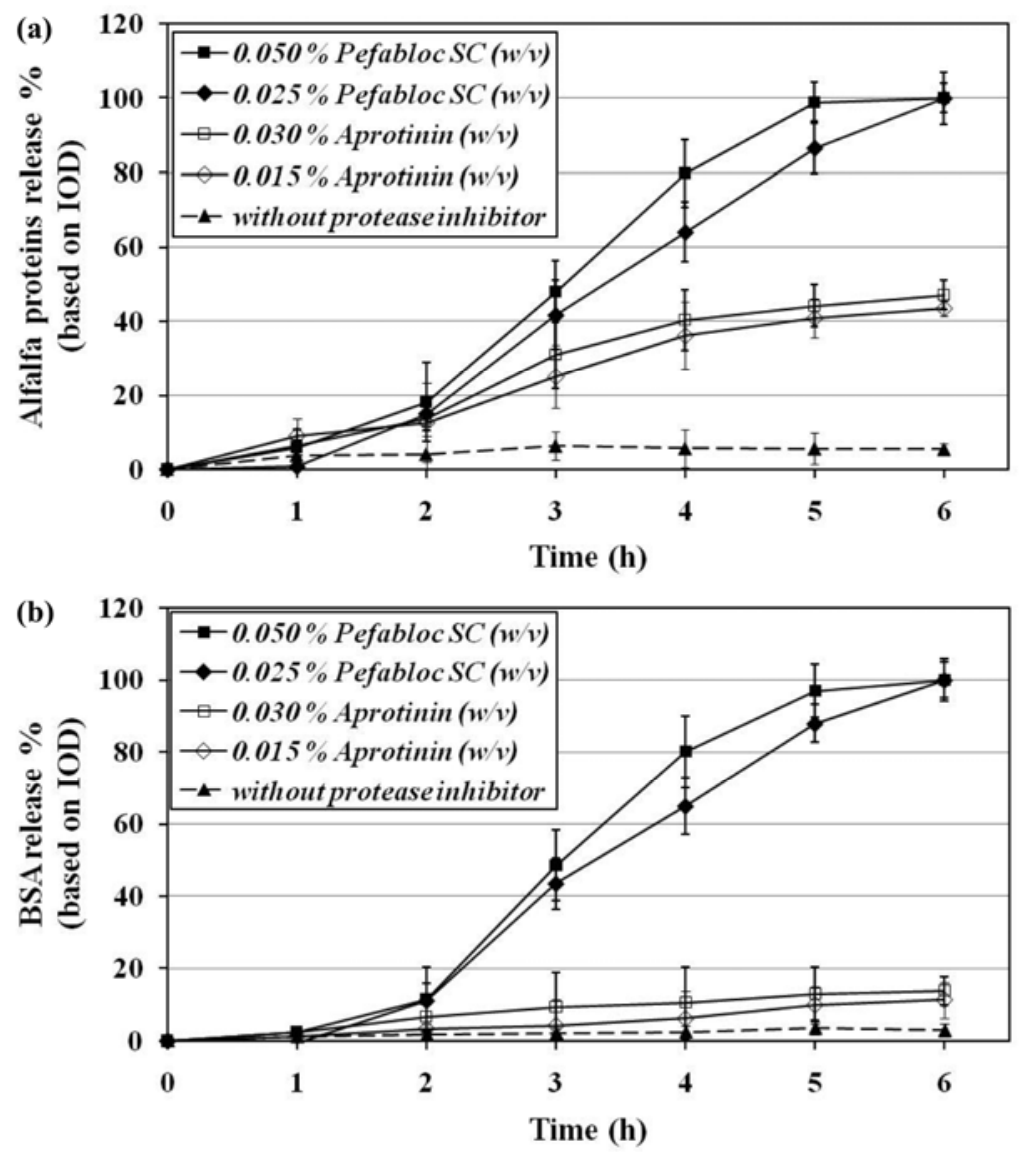

Figure 3. Release of proteins from CMS tablets in simulated intestinal fluid (SIF/USP) with protease inhibitors in dissolution media. The tablets $(300 \mathrm{mg})$ loaded with $30 \%$ of (a) APE or (b) APE + BSA $(1 \%)$, were incubated $\left(37^{\circ} \mathrm{C}\right.$ and $50 \mathrm{rpm}$ ) for $2 \mathrm{~h}$ in $10 \mathrm{~mL}$ of simulated gastric fluid containing pepsin (SGF/USP) and then transferred to $10 \mathrm{~mL}$ of SIF with pancreatin supplemented or not with Aprotinin $(0.015 \%$ or $0.030 \% \mathrm{w} / \mathrm{v})$ or Pefabloc SC $(0.025 \%$ or $0.050 \% \mathrm{w} / \mathrm{v})$. The samples were withdrawn every hour for $6 \mathrm{~h}$ and proteins stability was determined by SDS-PAGE. Volume of the samples: $10 \mu \mathrm{L} /$ well; IOD, integrated optic density ( $\mathrm{n}=3)$.

To confirm the stability of the alfalfa proteins and BSA in the presence of protease inhibitors, nonformulated free proteins were incubated during $6 \mathrm{~h}$ $\left(37^{\circ} \mathrm{C}\right.$ and $\left.50 \mathrm{rpm}\right)$ in SIF with pancreatin and $2.5 \mathrm{mg}$ of Pefabloc SC added to the incubation medium. It was found that the electrophoretic pattern of Alfalfa proteins and BSA remained unchanged throughout the $6 \mathrm{~h}$ treatment with pancreatic enzymes (Figure 5a and b, lanes 4-10). This indicates that Pefabloc SC provides enough protection to ensure structural stability (Figure 5c).

To determine the stability of enzymatic activity, APE with Lipase $1 \%(\mathrm{w} / \mathrm{w})$ as marker was incubated during $6 \mathrm{~h}\left(37^{\circ} \mathrm{C}\right.$ and $\left.50 \mathrm{rpm}\right)$ in SIF containing pancreatin, with or without $2.5 \mathrm{mg}$ of Pefabloc SC in the media. Higher lipase activity was observed in the presence of Pefabloc SC when compared to the media with no inhibitors (Figure $6 a)$. Thus, the delivery of proteins in SIF containing pancreatin from tablets loaded with $30 \%$ APE with Lipase $1 \%(\mathrm{w} / \mathrm{w})$, with or without Pefabloc SC $(1.6 \% \mathrm{w} / \mathrm{w})$ in the formulation, was evaluated over time. After $6 \mathrm{~h}$ of release, the lipase activity in dissolution media from tablets containing Pefabloc $\mathrm{SC}$ was $30 \%$ higher than from those without protease inhibitors (Figure 6b). 

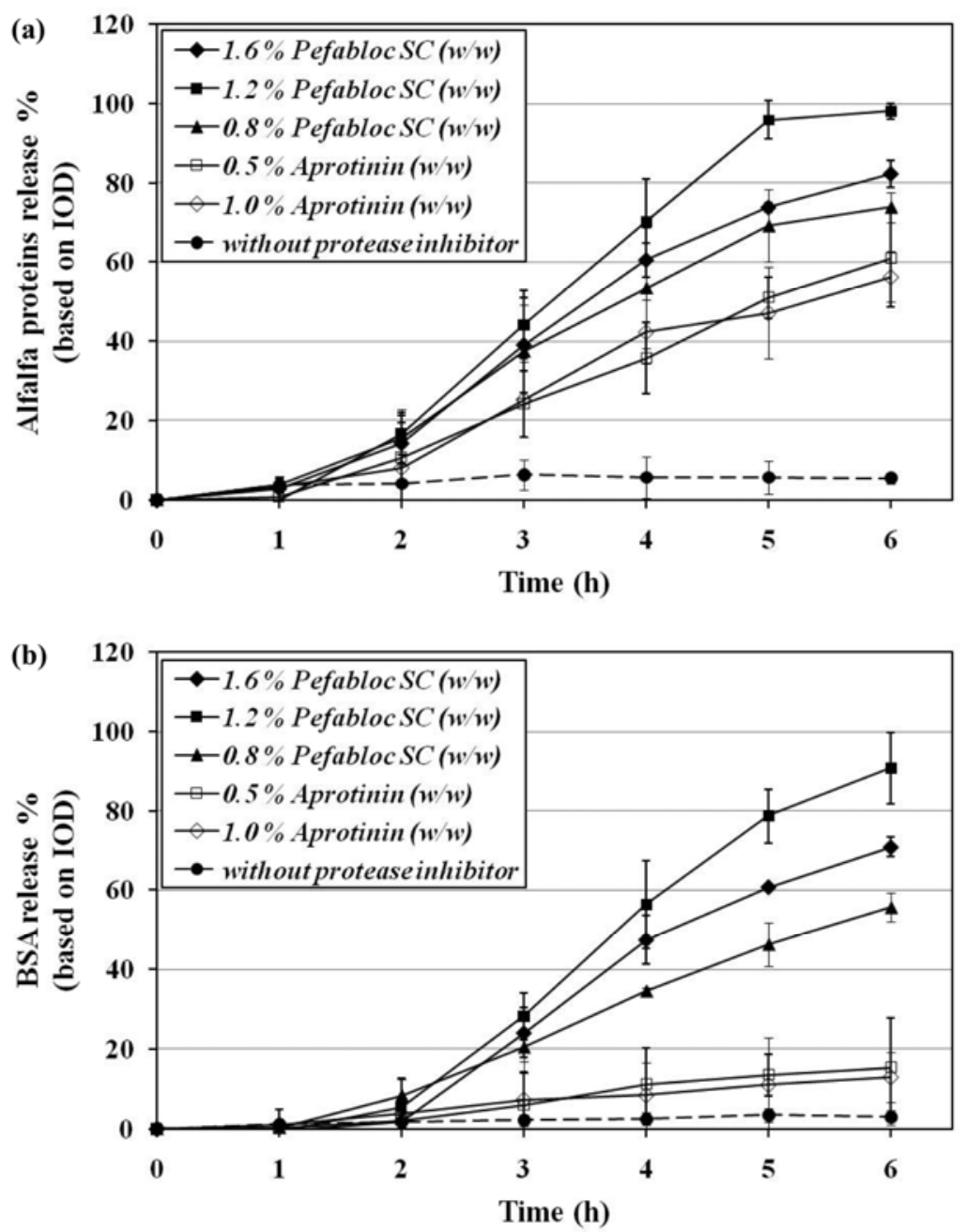

Figure 4. Release of proteins from CMS tablets in simulated intestinal fluid (SIF/USP) with protease inhibitors included in formulation. The tablets $(300 \mathrm{mg})$ with or without Pefabloc SC $(1.6 \%, 1.2 \%$ or $0.8 \% \mathrm{w} / \mathrm{w})$ or Aprotinin $(0.5 \%$ or $1.0 \%$ $\mathrm{w} / \mathrm{w}$ ) and with $30 \%$ of (a) APE or (b) APE+ BSA (1\%), were incubated $\left(37{ }^{\circ} \mathrm{C}\right.$ and $\left.50 \mathrm{rpm}\right)$ for $2 \mathrm{~h}$ in $10 \mathrm{~mL}$ of simulated gastric fluid containing pepsin (SGF/USP) and then transferred to $10 \mathrm{~mL}$ of SIF with pancreatin. The samples were withdrawn every hour for $6 \mathrm{~h}$ and protein stability was determined by SDS-PAGE. Volume of the samples: $10 \mu \mathrm{L} / \mathrm{well}$; IOD, integrated optic density $(n=3)$.

\section{DISCUSSION}

Since most proteins are sensitive to digestive proteolysis (pepsin, pancreatic protease), their immunogenicity in the context of oral vaccines may be damaged and the immune response at mucosal sites may be compromised. Thus, a formulation providing good protection, not only from gastric but also from intestinal proteolysis, is needed to maintain their immunogenic and therapeutic properties. The CMA has been shown to provide certain stability in gastric condition due to its $\mathrm{pH}$ sensitive properties (11-13). In intestinal conditions, when small molecules are formulated, the CMA provides a progressive release of the bioactive agent. This is probably due to pancreatic alphaamylase that acts on CMS as a substrate.

The protein release was faster in SIF containing pancreatin than in SIF without enzymes, probably due to erosion of the CMS matrix (13). 

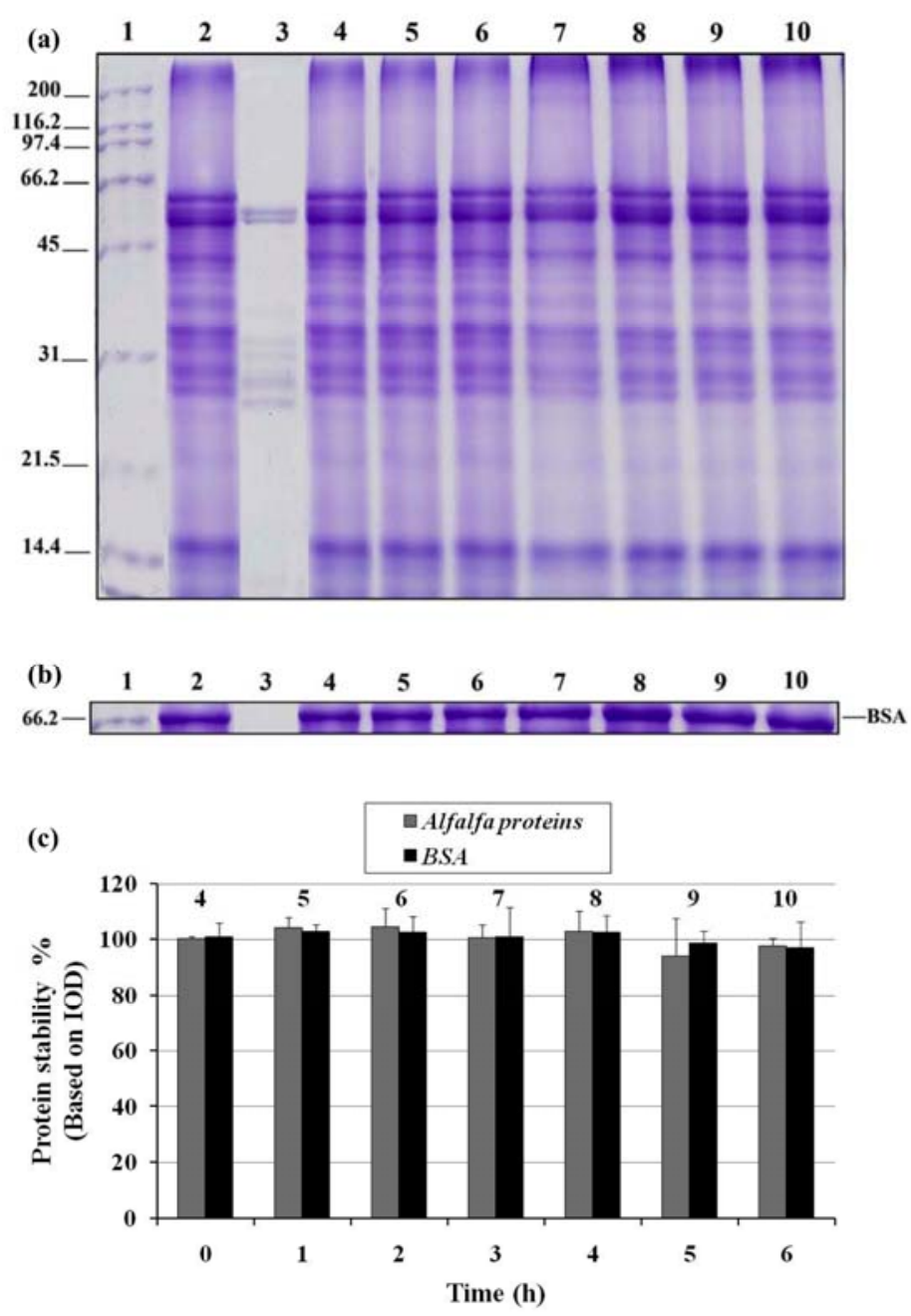

Figure 5. Stability of proteins in simulated intestinal fluid (SIF/USP) containing pancreatin and protease inhibitor (Pefabloc SC): (a) SDS-PAGE pattern of alfalfa proteins; (b) SDS-PAGE of BSA tracer (1\%) in alfalfa protein extract (APE); (c) Densitometric analysis of SDS-PAGE based on IOD. Electrophoretic profiles: molecular weight of protein markers $(\mathrm{kDa})$ (lane 1); Free (non-formulated) proteins in phosphate buffer solution (lane 2); Pancreatin in simulated intestinal fluid (lane 3); free (non-formulated) proteins in SIF with pancreatin and Pefabloc SC $(0.025 \%(\mathrm{w} / \mathrm{v}))$ after $0 \mathrm{~h}$ (lane 4$), 1 \mathrm{~h}($ lane 5), $2 \mathrm{~h}(6), 3 \mathrm{~h}(7), 4 \mathrm{~h}(8), 5 \mathrm{~h}(9), 6 \mathrm{~h}$ (10). Volume of the samples: $10 \mu \mathrm{L} /$ well; IOD, integrated optic density (n=3).

The increased release rate, in the presence of pancreatic enzymes, may be due to the fact that starch substituted with CM-groups is still an alphaamylase substrate (12). Consequently, the erosion of the polymeric matrix, in concert with deprotonation of CM- groups in neutral $\mathrm{pH}$, can accelerate the release of the protein content. Proteins are often stabilized by associative interactions (ionic and hydrogen associations, Van der Waals forces). The fact that at lower bioactive principle loading (more CMS excipient in the tablet) the protein release was faster, suggests that CMS excipient could also act as a disintegrant.

In the case of peptides or therapeutic proteins with intestinal or colonic targeting, the pancreatic protease (trypsin and chymotrypsin) and other intestinal protease can damage the bioactive molecules. 

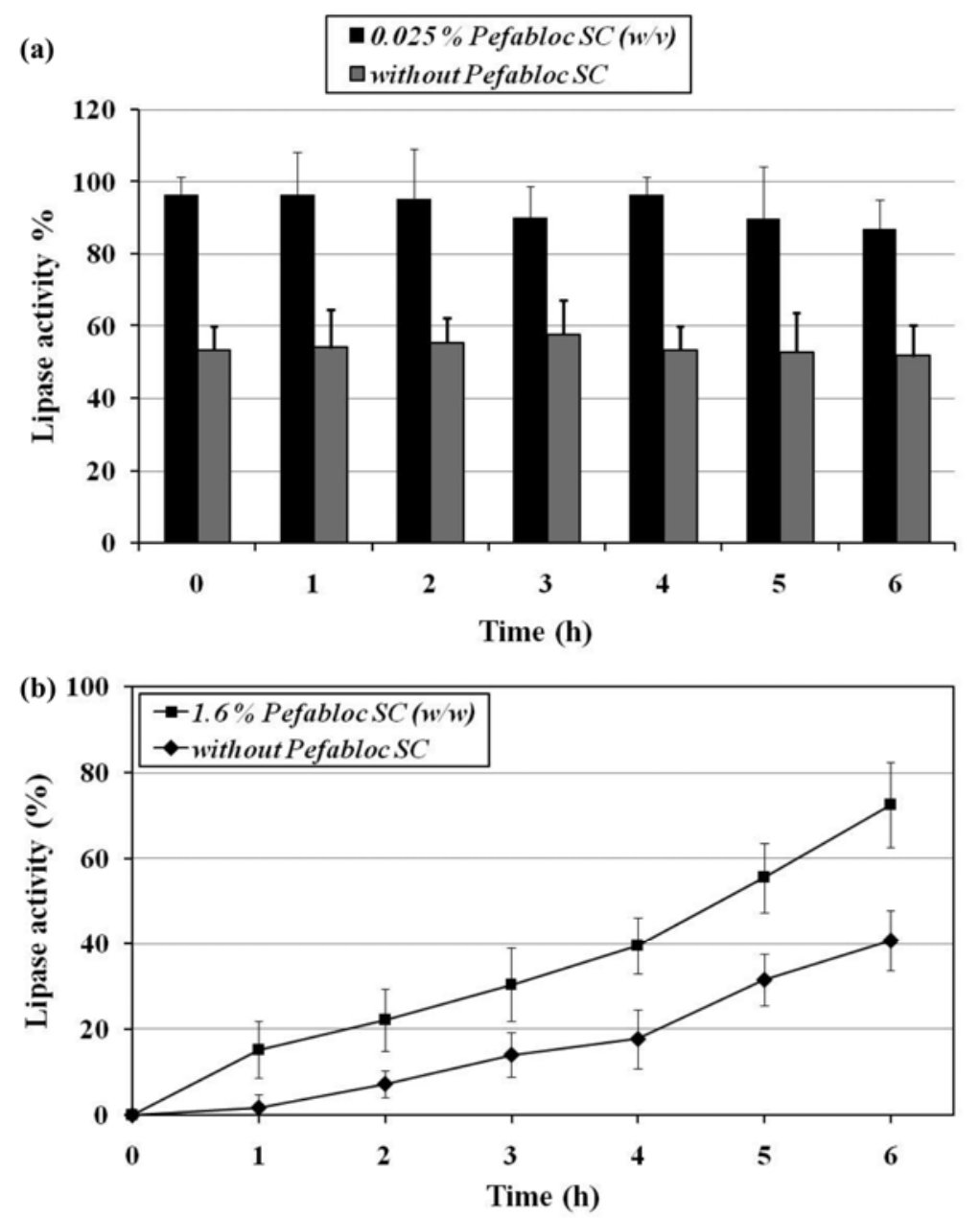

Figure 6. Lipase as a marker for protein formulation: (a) Lipase activity in simulated intestinal fluid (SIF/USP) from free (non-formulated) APE containing Lipase (1\%) incubated in SIF with pancreatin and with or without Pefabloc SC $(0.025 \%$ w/v). (b) Lipase activity from CMS tablets $(300 \mathrm{mg})$ loaded with $30 \%$ of APE with Lipase (1\%) containing or not Pefabloc SC $(0.050 \% \mathrm{w} / \mathrm{w})$, were incubated $\left(37^{\circ} \mathrm{C}\right.$ and $\left.50 \mathrm{rpm}\right)$ for $2 \mathrm{~h}$ in $10 \mathrm{~mL}$ of simulated gastric fluid containing pepsin (SGF/USP) and then transferred to $10 \mathrm{~mL}$ of SIF with pancreatin. The samples were withdrawn every hour for $6 \mathrm{~h}$ for the Lipase activity assay $(n=3)$.

To circumvent this problem, a protease inhibitor was added to the formulated peptides in order to ensure intestinal stability of bioactive peptides when released from CMS formulation. To our knowledge, this is the first attempt to use a protease inhibitor within the formulation. This approach differs from the associated treatment with inhibitors which are separately delivered in the dissolution fluid (18). In our study, the in situ release of inhibitors together with the bioactive agent will increase local efficiency and avoid its nonspecific dissipation.

Generally, enteric coating techniques are needed to ensure gastric protection of dosage forms. These procedures may involve hot air flow to evaporate solvent, increasing the alteration risk of heat sensitive materials (25). Coating-free CMS monolithic dosage forms, formulated in one 
compression step, were found to provide satisfactory gastro-protection $(10,11)$. This is of interest for further developments since eliminating additional steps and materials for enteric coating.

There are several commercial CMS based products, but they are cross linked and used as disintegrants (26). Their action resides in the capacity of CMS to disintegrate, particularly at neutral $\mathrm{pH}$ (higher than pKa 4.2 of CMS) when carboxylic groups ionically retain $\mathrm{Na}^{+}$and consequently hydrate, swell, and induce disintegration. The additional cross linking of these starch excipients (26) reduces the flexibility of chains and prevents further stabilization by hydrogen association (13) involving carboxylic and hydroxylic groups. Thus, also the hydroxyl groups are free and available to hydrate, swell and induce disintegration. In our case, with the noncross-linked CMS, there is an interesting balance between the important hydration and swelling of carboxylate groups and the chain stabilization by hydrogen bonding.

In plant protein formulation, particularly following compression, it is also possible to establish ionic interactions involving the free amino groups from lysine and carboxylic groups from formulated proteins (glutamate and aspartate) and those of CMS excipient. Since proteins can be digested by pancreatic proteolytic enzymes, the delivery of protease-sensitive proteins into the small intestine, without structural and functional damages, constitutes a challenge. An interesting way to prevent protein degradation is the use of protease inhibitors. Larionova et al. (18) used Aprotinin (a reversible serine protease inhibitor) in formulations to prevent proteolytic degradation of bioactive peptides for intestinal delivery. On the other hand, the active agent Pefabloc SC irreversible serine protease inhibitor has already been included in Complete $^{\mathrm{TM}}$ tablets as commercial product. We have compared Aprotinin and Pefabloc SC as protease inhibitors in the dissolution media. Furthermore, we have introduced inhibitors to our CMS formulations. This is different from the previous approaches using separate inhibitors administration.

Structural integrity and biological functionality of the immunogenic proteins are essential for an adequate immune response. To address this point, lipase was added to APE as a model tracer and its enzymatic activity was evaluated. Higher lipase activity was observed in the presence of Pefabloc SC compared to media without inhibitors.

The interest in using oral vaccination consists not only in efficient local delivery of antigens for secretion of antibodies, but also in the fact that the formulations are easier to develop (less requirements of sterile conditions) and expected to be faster accepted by regulatory organizations. For animals, the amount of antigenic material required for oral immunization depends of the bodyweight. Verdonck et al. used a dosage of $2 \mathrm{mg}$ of F4 fimbriae for induction of an F4-specific intestinal immune response in piglets (27). In our study, we developed formulations based on vegetal protein extracts with no purification steps before compression. Due to the presence of protesases inhibitors, less degradation of antigenic material will give a better intestinal specific response.

In conclusion, our study shows the feasibility to deliver stable bioactive proteins into intestinal environment using CMS excipients supplemented with serine protease inhibitors for their protection. In addition to its protective role, the CMS excipient allows the release of the bioactive agents in less than $6 \mathrm{~h}$, fitting well with the upper intestinal transit. Future work will focus on the application of these gastro-intestinal resistant formulations in vivo in the context of oral vaccine purposes.

\section{ACKNOWLEDGEMENTS}

This work was supported by funds from the Natural Sciences and Engineering Research Council of Canada (NSERC) (strategic grant \# 322085) to D. Archambault (PI), F. Sarhan and M. A. Mateescu, and from "La Fédération des Producteurs de Porcs du Québec" (FPPQ), and "Le Conseil pour le Développement de l'Agriculture du Québec" (CDAQ) to D. Archambault. NSERC support to M. A. Mateescu and a graduate studentship to P. De Koninck by "Le Centre de Recherche en Infectiologie Porcine (CRIP), Université de Montréal" are gratefully acknowledged. 


\section{NOVELTY OF THE WORK}

To our knowledge, this is the first report showing protease inhibitors added to the formulation to protect plant proteins from proteolytic degradation by pancreatic enzymes. 2. The CMS matrix can protect plant protein extract from the gastric acidity and digestive proteolysis (pepsin, trypsin, chymotrypsin) formulated without any coating, allowing the release of the bioactive materials within $6 \mathrm{~h}$ for various intestinal targets. Consequently, the bioactive materials formulated with CMS excipients and protease inhibitors are released at time-points corresponding with the small intestine transit and have their structural and functional properties maintained. These properties are important for formulation of bioactive compounds targeted to mucosal immunity.

Abbreviations: CM, carboxymethyl; CMS, Carboxymethyl Starch; DS, Degree of Substitution; SGF, Simulated Gastric Fluid; SIF, Simulated Intestinal Fluid; APE, Alfalfa Protein Extract; BSA, Bovine Serum Albumin; SDS-PAGE, Sodium Dodecyl Sulfate-PolyAcrylamide Gel Electrophoresis; PBS, Phosphate Buffer Saline solution; IOD, Integrated Optic Density.

\section{REFERENCES}

1. Holmgren J, Czerkinsky C, Eriksson K, Mharandi A. Mucosal immunization and adjuvants: a brief overview of recent advances and challenges. Vaccine, 2003; 21 : S2/89S2/95.

2. Huang Z, Dry I, Webster D, Struynell R, Wesselingth S. Plant-derived measles virus hemagglutinin protein induces neutralizing antibodies in mice. Vaccine, 2001; $19: 2163$ 2171.

3. Streatfield SJ, Lane JR, Brooks CA, Barker DK, Poage ML, Mayor JM, Lamphear BJ, Drees CF, Jilka JM, Hood EE, Howard JA. Corn as a production system for human and animal vaccines. Vaccine, 2003; $21: 812-815$.

4. Erickson, L.; Yu, W.J.; Brandle, J.; Rymerson, R., Molecular Farming of Plants and Animals for Human and Veterinary Medicine. Kluwer Academic Publishers, the Netherlands, 2002.
5. Acheson DW, Luccioli S. Microbial-gut interactions in health and disease. Mucosal immune responses. Best Pract Res Clin Gastroenterol, 2004; 18 : 387-404.

6. Kerneis S, Bogdanova A, Kraehenbuhl J-P, Perringault E. Conversion by Peyer's patch lymphocytes of human enterocytes into M cells that transport bacteria. Sciences, 1997; 277 : 949-952.

7. Ogra PL, Faden H, Welliver RC. Vaccination atrtegies for mucosal immune responses. Clin Microbiol Rev, 2001; 14 : 430-445.

8. Langguth P, Bohner V, Heizmann J, Merkle HP, Wolffram S, Amidon GL, Yamashita S. The challenge of proteolytic enzymes in intestinal peptide delivery. J Control Release, 1997; 46 : 39-57.

9. Roper H. Applications of starch and its derivatives, Carbohydr Eur, 2001; 15 : 14-21.

10. Mulhbacher J, Ispas-Szabo P, Mateescu MA. Cross-linked high amylose starch derivatives for drug release. II. Swelling properties and mechanistic study. Int J Pharm, 2004; 278 : 231238.

11. Calinescu C, Mulhbacher J, Nadeau E, Fairbrother JM, Mateescu MA. Carboxymethyl high amylose starch (CM-HAS) as excipient for Escherichia coli oral formulations. Eur J Pharm Biopharm, 2005; 60 : 53-60.

12. Calinescu C, Nadeau E, Mulhbacher J, Fairbrother JM, Mateescu MA. Carboxymethyl high amylose starch for F4 fimbriae gastroresistant oral formulations. Int $\mathrm{J}$ Pharm, 2007; $343: 18-25$.

13. Massicotte LP, Baille WE, Mateescu MA. Carboxylated high amylose starch as pharmaceutical excipients: Structural insights and formulation of pancreatic enzymes. Int $\mathbf{J}$ Pharm, 008; 356 : 212-223.

14. Brouillet F, Bataille B, Cartilier L. Highamylose sodium carboxymethyl starch matrices for oral, sustained drug-release: formulation aspects and in vitro drug-release evaluation. Int J Pharm, 2008; 356 : 52-60.

15. Hsieh CC, Hernández-Ledesma B, Jeong HJ, Park JH, de Lumen BO. Complementary roles in cancer prevention: protease inhibitor makes the cancer preventive peptide lunasin bioavailable. PLoS One, 2010; 5 : e8890.

16. Esposito E, Cortesi R, Bortolotti F, Manegatti E, Nastruzzi C. Production and characterization of biodegradable microparticles for the 
controlled delivery of proteinase inhibitors. Int $\mathrm{J}$ Pharm, 1996; 129: 263-273.

17. Shi C, Zhao X, Wang X, Zhao L, Andersson R. Potential effects of PKC or protease inhibitors on acute pancreatitis-induced tissue injury in rats. Vascul Pharmacol, 2007; 46 : 406-411.

18. Larionova NV, Ponchel G, Duchêne D, Larionova NI. Biodegradable cross-linked starch:protein microcapsules containing proteinase inhibitor for oral protein administration. Int J Pharm, 1999; 189 : 171178.

19. Yamamoto A, Taniguchi T, Rikyuu K, Tsuji T, Fujita T, Murakami M, Muranishi S. Effects of various protease inhibitors on the intestinal absorption and degradation of insulin in rats. Pharm Res, 1994; 11 : 1496-1500.

20. Tiourina, O., Hamdi, G., Larionova, N., Duchene, D., Ponchel, G., Preparation and characterization of polymethacryloyl starch microspheres loaded with basic pancreatic trypsin inhibitor. Proc. 2nd World Meeting Pharmaceutics Biopharmaceutics and Pharmaceutical Technology, Paris, pp. 539-540, 1998.

21. Dentan C, Tselepis AD, Chapman MJ, Ninio E. Pefabloc, 4-[2 aminoethyl]-benzenesulfonyl fluoride, is a new, potent nontoxic and irreversible inhibitor of PAF-degrading acetylhydrolase. Biochim Biophys Acta, 1996; 1299 : 353-357.
22. Westberg $\mathrm{C}$, Benkestock $\mathrm{K}$, Fatouros $\mathrm{A}$, Svensson M, Sjostrom B. Hexarelin-evaluation of factors influencing oral bioavailability and ways to improve absorption. J Pharm Pharmacol, 2001; 53 : 1257-1264.

23. Schell HD, Serban M, Mateescu MA, Bentia T. Acid and basic amylose ionic exchangers. Rev Roumaine Chim, 1978; 23 : 1143-1147.

24. Capraro J, Magni C, Scarafoni A, Duranti M. Susceptibility of lupin gamma-conglutin, the plasma glucose-lowering protein of lupin seeds, to proteolytic enzymes. J Agric Food Chem, 2009; 57 : 8612-8616.

25. Sauer D, Zheng W, Coots LB, McGinity JW. Influence of processing parameters and formulation factors on the drug release from tablets powder-coated with Eudragit L 100-55. Eur J Pharm Biopharm, 2007; 67 : 464-475.

26. Zhao N, Augsburger LL. Functionality Comparison of 3 Classes of Superdisintegrants in Promoting Aspirin Tablet Disintegration and Dissolution. AAPS PharmSciTech, 2005; 6 : E634-E640.

27. Verdonck F, Joensuu JJ, Stuyven E, De Meyer J, Muilu M, Pirhonen M, Goddeeris BM, Mast J, Niklander-Teeri V, Cox E. The polymeric stability of the Escherichia coli F4 (K88) fimbriae enhances its mucosal immunogenicity following oral immunization. Vaccine. 2008; 26 : 5728-5735. 